\title{
Jamaica: Interim Staff Report Under Intensified Surveillance
}

This interim staff report for Jamaica was prepared by a staff team of the International Monetary Fund. It is based on the information available at the time it was completed on June 23, 2005. The views expressed in this document are those of the IMF staff and do not necessarily reflect the views of the government of Jamaica or the Executive Board of the IMF.

The policy of publication of staff reports and other documents by the IMF allows for the deletion of market-sensitive information.

To assist the IMF in evaluating the publication policy, reader comments are invited and may be sent by e-mail to publicationpolicy@imf.org.

Copies of this report are available to the public from

International Monetary Fund • Publication Services

700 19th Street, N.W. • Washington, D.C. 20431

Telephone: (202) 6237430 • Telefax: (202) 6237201

E-mail: publications@imf.org • Internet: http://www.imf.org

Price: $\$ 15.00$ a copy

\section{International Monetary Fund \\ Washington, D.C.}





\title{
INTERNATIONAL MONETARY FUND
}

\author{
JAMAICA \\ Interim Staff Report Under Intensified Surveillance \\ Prepared by the Western Hemisphere Department \\ (In consultation with other departments) \\ Approved by Caroline Atkinson and Matthew Fisher
}

June 23, 2005

- Discussions. Discussions were held in Kingston during April 20-May 3, 2005. The mission team-comprising Antônio Furtado (head), Goohoon Kwon, and Rafael Romeu (all WHD); and Piyabha Kongsamut (PDR) — met with finance minister Omar Davies; the outgoing and the incoming financial secretaries, Shirley Tyndall and Colin Bullock; Bank of Jamaica governor Derick Latibeaudière; other senior officials; opposition leader Bruce Golding; representatives of local financial institutions; and representatives of the official external creditors and donors. Mr. Richard Campbell (OED) attended the concluding policy discussions.

- Intensified surveillance. Intensified surveillance of the authorities' medium-term macroeconomic and structural policies was requested by the authorities and supported by the Executive Board at the time of the conclusion of 2004 Article IV consultation. The underlying economic strategy was formulated by the authorities without reaching prior understandings with Fund staff. Interim staff reports are to be prepared for information of the Executive Board in between Article IV consultations, the first of which was issued on January 31, 2005 (IMF Country Report No. 05/61). As with past staff reports, the authorities expect to authorize publication of this interim report following its issuance to the Executive Board.

- Last Article IV consultation. The 2004 Article IV consultation was concluded by the Executive Board on August 3, 2004. Directors supported the priority placed by the authorities on bringing down the public debt-to-GDP ratio while noting that the magnitude and duration of the fiscal adjustment envisaged by the authorities are subject to considerable risks. They emphasized that reform measures will be critical for the success of the authorities' economic strategy.

- Political setting. Despite the adjustment measures over the last two years, including major wage restraint in the public sector, the political situation has remained stable. The governing People's National Party (PNP) retains a comfortable majority in parliament and elections are due by 2007. However, Prime Minister Patterson has indicated his intention to resign from office, which would trigger the choice of a successor from within the PNP for the balance of the current term.

- Fund relations. Jamaica has accepted the obligations of Article VIII, Sections 2, 3, and 4 of the Articles of Agreement. A multiple currency practice remains, which is subject to Fund jurisdiction. Relations with the Fund are detailed in Appendix I. 


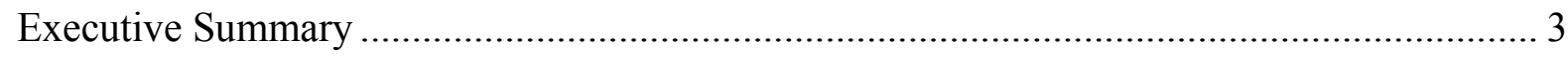

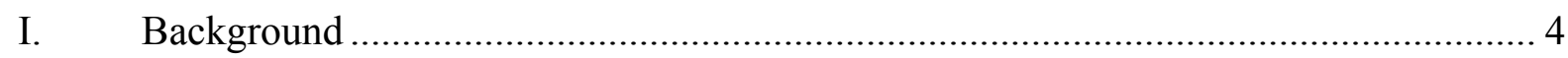

II. Developments Under the Authorities’ Program in FY 2004/05 .............................. 4

III. The Authorities’ Macroeconomic Framework for FY 2005/06 _.............................. 6

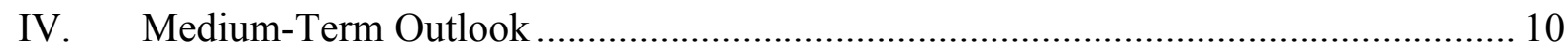

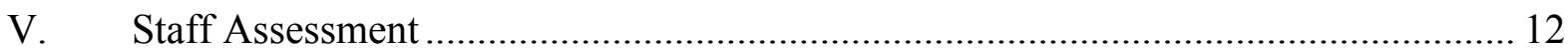

Box

1. Authorities' Semi-Annual Macroeconomic Targets for FY 2005/06 _....................... 9

\section{Figure}

1. Selected Macroeconomic Indicators, FY 2001/02-FY 2004/05 ............................ 15

Tables

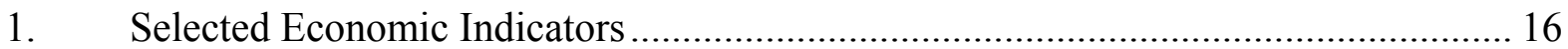

2. Summary of Central Bank Operations .................................................................. 17

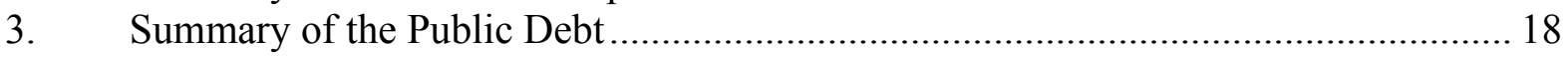

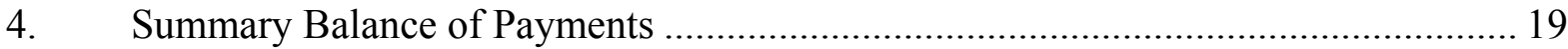

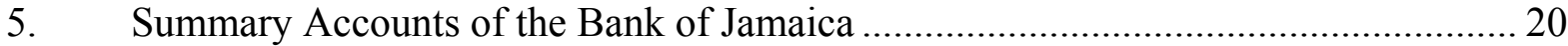

6. Summary Monetary Survey ................................................................................. 21

7. Selected Vulnerability Indicators .................................................................... 22

8. Public Debt Sustainability Framework, FY 1994/95-FY 2008/09 ......................... 23

Appendix

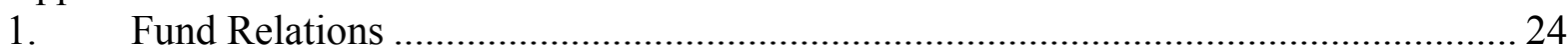




\section{EXECUTIVE SUMMARY}

- Following the adverse economic impact of Hurricane Ivan, the outlook for FY 2005/06 is for a rebound in growth in the context of broad macroeconomic stability. Real GDP growth slowed and damage to agriculture contributed to double-digit inflation in FY 2004/05. While the hurricane also contributed to deviations in relation to FY 2004/05 fiscal targets, the public debt-GDP ratio continued to decline. The external current account deficit widened but strong capital inflows helped lower domestic interest rates, strengthen international reserves, and maintain exchange rate stability. In FY 2005/06, real GDP growth is expected to rise to $3 \frac{1}{2}$ to 4 percent, the public debt to decline to $125-130$ percent of GDP, and inflation to return to single digits.

- While global liquidity conditions have been very favorable, the generally positive results of the last two years owe much to renewed fiscal consolidation, reflected in very high primary budget surpluses. A key factor for this consolidation has been the high degree of national ownership, evidenced notably by continued adherence to the Memorandum of Understanding agreed in February 2004 between the government and the trade unions; and by the recent passage of a balanced budget for FY 2005/06 incorporating the first stage of a comprehensive tax reform.

- The government's balanced budget target for this fiscal year, which is of landmark importance for Jamaica's strategy to reduce the debt burden, appears within reach. The mission encourages the authorities to keep expenditure strictly within the budgeted levels and to pursue vigorously their efforts at improving tax administration and raising taxpayer compliance.

- Achieving the envisaged further reduction in the public debt-GDP ratio to 100 percent over the next four years will be challenging and demand high fiscal discipline. In the budget area, exceptional restraint will be needed to sustain the required primary surpluses in excess of 13 percent of GDP. In particular, the government will have to devise policies during the current fiscal year to keep the wage bill under control following the expiration of the MOU in early 2006. Strict control must also be maintained over off-budget expenditure and debt guarantees. The authorities are encouraged to implement fully the planned restructuring of Air Jamaica. The recent adjustment of water tariffs and the establishment of an annual tariff review mechanism have also been important positive steps.

- The reductions in policy interest rates in FY 2004/05 were appropriate. However, with inflation still above international levels and prospects of global interest rate hikes, the staff advises caution with respect to the pace of further reductions in policy interest rates.

- The staff welcomes the continuing progress towards strengthening the regulatory and supervisory framework of the financial system. The banking sector appears to remain generally sound and profitable. Recent positive steps to reduce vulnerabilities in the securities industry and to strengthen the AML/CFT framework should be followed by further enhancements that may be identified in the context of the upcoming FSAP. 


\section{BACKGROUND}

1. In early 2004, the Government articulated a medium-term economic strategy to address high indebtedness and low growth, in the context of a broader socio-economic policy initiative. The government's "Medium-Term Socio-Economic Policy Framework," which resulted from wide public consultations and enjoys strong donor support, comprises a broad range of policies aimed at placing Jamaica as close as possible to compliance with the Millennium Development Goals (MDGs). The government's economic strategy seeks to reduce the extraordinarily high public debt-GDP ratio (1431/2 percent in FY 2003/04) to around 100 percent by FY 2008/09. This objective is being pursued through intensified fiscal adjustment - including balancing the budget in FY 2005/06 (April-March fiscal year) - and higher growth. ${ }^{1}$

2. At the conclusion of the 2004 Article IV consultation, the Executive Board endorsed the authorities' request for intensified surveillance of their medium-term macroeconomic strategy. In the first interim report under intensified surveillance (IMF Country Report No. 05/61), staff found that the authorities' strategy remained broadly on track although deviations from the FY 2004/05 targets, due mainly to the impact of Hurricane Ivan, would make it more challenging to achieve the objective of balancing the budget in FY 2005/06.

\section{Developments Under the AUthorities’ Program in FY 2004/05}

3. As expected in the aftermath of Hurricane Ivan, the targets under the authorities' macroeconomic program for FY 2004/05 were not fully met. Real GDP grew at about $2 \frac{1}{2}$ percent in the first three quarters of 2004 , but slowed sharply in the fourth quarter due primarily to the adverse effects of the hurricane on agriculture, mining and tourism. As a result, the economy is estimated to have grown by only 0.7 percent during FY 2004/05

(Table 1 and Figure 1). Inflation picked up in the fourth quarter of 2004 largely reflecting the price impact of crop damage, and remained in the double digits for the whole of FY 2004/05. Unemployment rose slightly, from 11.4 percent in 2003 to 11.7 percent on average in 2004.

4. The hurricane contributed to deviations in relation to FY 2004/05 fiscal targets. Hurricane-related expenditure amounting to about 1 percent of GDP, and weaker tax revenues, led to a shortfall of 2 percentage points of GDP in the primary surplus relative to the target (Table 2). Still, the overall budget deficit narrowed by about 1.5 percentage points of GDP, to 5 percent of GDP, reflecting a decline in domestic interest rates from the elevated levels of the preceding fiscal year. The overall deficit of the central government, which includes off-budget expenditure, ${ }^{2}$ narrowed from 9.7 percent of GDP in FY 2003/04 to

\footnotetext{
${ }^{1}$ A detailed discussion of the authorities' strategy is contained in the 2004 Article IV consultation report (IMF Country Report No. 04/263).

${ }^{2}$ Off-budget expenditure is defined in the staff documents as the issuance of government debt related to central bank losses and to projects undertaken with deferred financing.
} 
7.1 percent of GDP in FY 2004/05. ${ }^{3}$ Gross government and government-guaranteed debt continued to decline in relation to GDP, from 144 percent in March 2004 to 139 percent in March 2005 (Table 3).

\section{The fiscal position has also been affected by financial weaknesses in some public} entities, which the authorities have now started to address. The weak operating position of the National Water Commission (NWC) led the government to assume some of its domestic debt early in the fiscal year, amounting to J\$1.4 billion ( 0.2 percent of GDP). Air Jamaica returned to state control in late 2004 after accumulating liabilities to the government totaling about US\$400 million (4.4 percent of GDP) and a similar amount of debt to private creditors over the ten-year period of private management. Regarding NWC, the government raised water tariffs by 15-18 percent in January 2005 and has also put in place a mechanism to review these tariffs annually to ensure that the NWC will be able to service remaining debt obligations. Regarding Air Jamaica, new management is finalizing a restructuring plan to downsize operations and improve efficiency. The aim is to reduce annual losses from US\$60 70 million to a maximum of US $\$ 30$ million in FY 2005/06 - to be financed by a budgetary subsidy - and to eliminate losses within three to four years. The authorities reserve the option of closing down the airline in the event of setbacks to the restructuring strategy.

\section{The external current account deficit widened but strong capital inflows helped} lower domestic interest rates, strengthen international reserves, and maintain exchange rate stability. The current account deficit widened from 6.8 percent of GDP in FY 2003/04 to $81 / 2$ percent of GDP in FY 2004/05 (Table 4). Imports rose rapidly, boosted by increased fuel payments, as well as FDI- and hurricane-related imports. ${ }^{4}$ Higher fuel imports reflected not only increased international prices, but also a five-month interruption in the operation of the local refinery (due to a major accident) which necessitated the importation of more expensive finished petroleum products in lieu of crude oil. Meanwhile, export and tourism receipts grew at a slower than expected rate because of the adverse effect of the hurricane on agriculture, mining, and tourism. The larger trade deficit was partly offset by an increase in official and private transfers. A strengthening of private capital inflows, attributable to ample global liquidity and positive market sentiment about Jamaica's fiscal adjustment effort, 5 allowed for an accumulation of international reserves in the context of exchange rate stability. While the real effective exchange rate appreciated by 5.8 percent in the 12 months through March 2005, it remains 11 percent below the 1998-2002 average.

\footnotetext{
${ }^{3}$ A broader concept, the nonfinancial public sector (which includes a set of 12 key public entities monitored under past Fund programs and staff-monitored programs) recorded an overall deficit of 6.5 percent of GDP in FY 2004/05, down from 8 percent of GDP in FY 2003/04.

${ }^{4}$ FDI-related imports were mainly for the tourism sector.

${ }^{5}$ Spreads on outstanding Jamaican Eurobonds tightened by about 150 basis points during FY 2004/05. In comparison, the B-rated component of the EMBIG spread tightened by only 70 basis points during the same period.
} 
7. The authorities continued to anchor monetary policy on a target for base money, in the context of a managed floating exchange rate regime. The accumulation of reserves, along with central bank losses associated with sterilization, far exceeded the targeted base money growth for the year. ${ }^{6}$ To sterilize the impact, the Bank of Jamaica (BOJ) continued to offer open market instruments (certificates of deposit) on tap. As a result, base money expanded by about 15 percent in FY 2004/05, in line with the target (Table 5). Broad money growth was somewhat slower, reflecting a modest reversal of dollarization (Table 6). The authorities noted that - reflecting confidence in Jamaica's policy framework and favorable external conditions - NIR had increased in the context of broad stability in the exchange rate, and demand for BOJ certificates of deposit had remained strong despite continued reductions in policy interest rates. They also noted that a smaller build-up of NIR and/or somewhat higher interest rates would probably have caused a larger real appreciation of the Jamaican dollar and hurt competitiveness.

8. The banking sector appears to remain generally sound and profitable although with significant exposure to the government (Table 7). At end-2004, the ratio of nonperforming loans to total loans stood at 3 percent - well within the prudential limit of 10 percent. Bank profitability declined marginally in 2004, due to a falling interest margin, but continued to compare favorably with the profitability of other banking systems in the region. Capital adequacy improved slightly to 8.5 percent at end-December 2004, $2 \frac{1}{2}$ percentage points above the prudential benchmark. The weighted capital adequacy ratio, at over 13 percent, comfortably exceeds the Basel I threshold. In the nonbank sector, a moderate-size insurance company collapsed in March 2005, brought down by large claims from Cayman Island clients in the wake of Hurricane Ivan. The collapse was an isolated event and the authorities did not intervene financially to save the company.

\section{The Authorities' MACROECONOMIC FrameWORK FOR FY 2005/06}

9. Real GDP growth is expected to rebound and the public debt ratio to decline to 125-130 percent of GDP in FY 2005/06, in the context of decelerating inflation and broadly stable international reserves. The authorities project a pick up in economic growth to 3.5-4.0 percent, underpinned by accelerated expansion in tourism, mining, and construction together with a full recovery in agriculture. On the inflation front, the authorities expect to contain 12-month inflation below 10 percent, including the impact of higher consumption taxes (see below). Towards these objectives, and to achieve a further decline in the public debt ratio, the authorities intend to balance the budget and maintain base money growth broadly unchanged from last year, while continuing to manage the exchange rate to avoid wide swings and protect competitiveness.

\footnotetext{
${ }^{6}$ As noted above, central bank losses are captured in the fiscal accounts as part of the overall government deficit.
} 


\section{Fiscal policy}

10. Despite the exogenous shocks experienced by the economy last year, the authorities have adopted a balanced budget for FY 2005/06 in line with their mediumterm strategy. In view of the FY 2004/05 outturn, this target implies a budgetary adjustment of 5 percentage points of GDP. While this would represent a sharp improvement in the fiscal position, there was concurrence during the discussions that the authorities' targets are achievable provided that the government maintains tight discipline on the expenditure side and fully implements the approved tax reform measures and ongoing efforts at raising taxpayer compliance.

- A substantial portion of the adjustment is expected to arise from a marked decline in the interest bill (by 3 percentage points of GDP), which had surged in FY 2003/04 and remained elevated in FY 2004/05 owing to the spike in interest rates in the wake of the near-crisis of two years ago.

- $\quad$ Wage and salary payments will fall considerably (2 percentage points of GDP) reflecting the full impact of the two-year Memorandum of Understanding (MOU) agreed with the trade unions in early $2004 .^{7}$

- $\quad$ On the revenue side, measures taken in the context of the ongoing tax reform are expected to yield over 1 1/2 percent of GDP, which would more than offset the loss of one-time receipts recorded in FY 2004/05. Most of the revenue increase will come from the General Consumption Tax (GCT) with increases in the standard GCT rate (from 15 percent to $16 \frac{1}{2}$ percent), and the preferential rate for the tourism sector (from 5 percent to $81 / 4$ percent) and a reduction in the coverage of zero-rated goods.

- $\quad$ On the financing side, full implementation of the fiscal program is expected to facilitate rolling over the substantial amount of maturing government debt (scheduled budgetary principal payments amount to about $21 \frac{1}{2}$ percent of GDP). ${ }^{8}$

11. Off-budget spending is expected to rise, somewhat offsetting the improvement in the on-budget balance. Debt issued to the central bank in compensation for high sterilization costs incurred in FY 2004/05 is projected to drive off-budget spending up by 1 percentage point of GDP, to 2.5 percent of GDP. The resulting overall deficit of the central government, as defined by the staff, together with a continuing surplus of the 12 major public entities

\footnotetext{
${ }^{7}$ While the MOU was already in effect last year, wages and salaries still increased somewhat in FY 2004/05 due to the clearance of statutory salary arrears. The FY 2005/06 budget does not contain such payments (see Table 2).

${ }^{8}$ The government issued in late May 2005 10-year Eurobonds amounting to US\$300 million, equivalent to about three-fifths of the external debt amortization due in FY 2005/06. The spread over U.S. Treasuries was 503 basis points, and - as was the case in previous issuesthe bonds did not incorporate collective action clauses.
} 
(0.7 percent of GDP), implies an overall public sector deficit of 1.8 percent of GDP (compared with 6.5 percent of GDP in FY 2004/05). Assuming no debt related to the deferred financing scheme is taken on this year as indicated by the authorities, ${ }^{9}$ the broad outlook is consistent with a decline in government and government-guaranteed debt to 126 percent of GDP.

\section{Monetary/exchange rate policy}

12. The central bank will target base money growth of 15 percent with a view to reducing inflation to single digits. The authorities believe that this pace of money growth is consistent with the anticipated pick-up in economic activity and the disinflation objective, while allowing a further modest increase in NIR. Credit to the private sector would grow faster than broad money, as fiscal consolidation frees up resources for the private sector. The exchange rate will continue to be determined under a managed float, with intervention geared mainly to smoothing out transitory fluctuations. In the event of downward pressures in the foreign exchange market, the authorities would continue to keep intervention to a minimum and implement a balanced and cautious monetary/exchange rate policy response, taking into account its impact on inflation, reserves, and the debt dynamics.

\section{External sector}

13. The external current account deficit is expected to widen somewhat further in FY 2005/06, as the trade and income balances deteriorate. A recovery in exports and tourism is expected to be offset by strong import growth largely due to high fuel costs and FDI-related imports, as well as higher external interest payments. Nevertheless, continued strong private capital inflows, largely through FDI, would allow for a modest build-up in NIR.

\section{Structural reforms}

14. In the fiscal area, the authorities have begun the first phase of tax reform drawing on the recommendations of the Tax Policy Review Committee. The reforms are intended to improve revenue elasticity; reduce tax complexity, so as to facilitate administration and improve compliance and equity; and enhance the competitiveness of the Jamaican economy (through lower taxation of labor income). The reforms implemented this year include raising the income tax threshold while simplifying and reducing the transfer tax and the property tax. In addition, as noted, the reforms have increased the GCT rates and reduced the coverage of zero-rated goods. These tax reforms are supported by ongoing efforts to strengthen tax administration and increase compliance, which produced a yield (including collection of tax arrears) amounting to about 1 percent of GDP in FY 2004/05, with a similar amount expected by the authorities in FY 2005/06.

\footnotetext{
${ }^{9}$ The authorities indicated that the use of deferred financing is being discontinued. The last assumption of debt under this heading is expected to take place in FY 2006/07, in an amount of $\mathrm{J} \$ 1.7$ billion ( 0.2 percent of GDP).
} 


\section{Box 1. Authorities' Semi-Annual Macroeconomic Targets for FY 2005/06}

Consistent with their economic program for FY 2005/06, the authorities have established semi-annual quantitative targets for the balance sheet of the BOJ and key budgetary indicators. The following targets have been adopted for September 2005 and March 2006:

Jamaica: Semi-Annual Quantitative Targets, FY 2005/06

\begin{tabular}{lrr}
\hline & Apr. 05-Sep. 05 & Apr. 05-Mar. 06 \\
\hline Change in net international reserves 1/ & US\$0 million & US\$98 million \\
Change in the net domestic assets 2/ & -J $\$ 0.2$ billion & J $\$ 0.3$ billion \\
Primary budget surplus & J $\$ 28.2$ billion & J $\$ 87.6$ billion \\
Overall budget deficit & J\$14.8 billion & J\$0 billion \\
\hline
\end{tabular}

$1 /$ The changes in NIR reflect the seasonal pattern of foreign exchange flows.

$2 /$ Defined as the difference between the change in base money and the change in NIR. The latter will be converted into Jamaica dollars at the accounting exchange rate of $\mathrm{J} \$ 63.89=\mathrm{US} \$ 1$.

15. In the financial sector, the authorities are taking steps to enhance the prudential framework for nonbank institutions. In this context, the Financial Services Commission (FSC) has recently introduced regulations to curtail the growth of the repo market, aiming to reduce the vulnerability of the securities industry to market risks. These include, inter alia, the imposition of minimum margin requirements for repurchase agreements and the strengthening of capital adequacy requirements (both effective end-2004). ${ }^{10}$ A National Pensions Act, passed in 2004, provides the basis for the FSC to license and regulate pension funds. The authorities are currently in the final stage of enacting regulations that are expected to encourage development of the sector by, inter alia, providing a transparent framework.

16. The legislative and regulatory framework for combating money laundering and the financing of terrorism is being strengthened. ${ }^{11}$ In this regard, amendments passed in

${ }^{10}$ The margin requirement for government securities was set at 1 percent in December 2004, and will increase to 3 percent in September 2005, and to 5 percent in December 2006. The capital adequacy ratio was set at 10 percent. The capital base and risk weights applied by the FSC are broadly consistent with the Basel I capital standards.

${ }^{11}$ An assessment of the AML/CFT framework was conducted by the Caribbean Financial Action Task Force (CFATF, the FATF-style regional body for the Caribbean region), during an on-site visit in April 2005. The final report will be discussed in October 2005, at the next CFATF Plenary meeting, following which it will be submitted to the Fund for a pro-forma review. 
late 2004 established comprehensive provisions for the BOJ and the FSC to share information with overseas regulators and strengthened their power to take regulatory action, including the revocation of licenses. In addition, a Terrorism Prevention Bill recently approved by parliament criminalizes the financing of terrorism. Moreover, amendments to the Money Laundering Act, and a new Financial Investigation Bill, were submitted to parliament in December 2004. According to the authorities, these amendments are intended to bring Jamaica's legislative framework in line with FATF requirements.

\section{MediuM-TERM OUTLOOK}

17. The baseline medium-term scenario is characterized by real annual growth of 34 percent, single-digit inflation, a modest rise in international reserves, and a further gradual decline in the public debt ratio. ${ }^{12}$ Growth would be driven primarily by tourism, mining and construction, and financed to an important degree by foreign direct investment. Monetary policy will target a further decline in inflation to 5-6 percent by FY 2008/09, underpinned by the maintenance of a balanced budget in FY 2006/07 and small surpluses in the next two years. The primary budget surplus would remain in the range of 13-14 percent of GDP even though the government's interest bill is projected to continue to decline as a percentage of GDP. These trends would provide for a slow but steady debt reduction to around 100 percent by FY 2008/09.

18. The medium-term outlook for the balance of payments is strongly influenced by expected foreign direct investments. Large investments in tourism and mining are expected to generate a strong demand for imports over the next two years, widening the current account deficit, particularly in FY 2006/07. As the projects come on stream, import growth will slow, contributing to a reduction in the current account deficit to around $4 \frac{1}{2}$ percent of GDP by FY 2008/09. The export-to-GDP ratio will likely decline over the next two years due mainly to expected price movements (associated with an erosion in the EU preferential treatment for sugar and bananas; and a projected decline in alumina prices) but would subsequently recover toward the end of the projection period. In the financial account, continued FDI-related private capital inflows should allow for a modest accumulation of reserves over the medium term, to about US\$2.3 billion. ${ }^{13}$

19. In view of the implementation risks associated with the fiscal stance, and the economy's vulnerability to exogenous shocks, the staff has prepared an illustrative scenario incorporating less favorable assumptions than those in the baseline scenario.

\footnotetext{
${ }^{12}$ The baseline scenario assumes full implementation of the authorities' economic strategy. It is virtually unchanged from the corresponding macroeconomic scenarios in the 2004 Article IV consultation report and in the first interim staff report under intensified surveillance of January 2005.

${ }^{13}$ Equivalent to 19 weeks of imports of goods and services, about 400 percent of short-term external debt and nearly 180 percent of short-term external debt and foreign currency deposits.
} 
The alternative scenario assumes no improvement in the primary budget compared with FY 2004/05, the assumption of an additional 0.7 percent of GDP in debt annually through the deferred financing scheme, and growth of government guaranteed debt in line with GDP. In addition, the scenario assumes no reduction in spreads between interest rates on domestic and foreign currency debt; and caps real GDP growth at 2.5 percent per year during the projection period. Under these assumptions, the public debt ratio would still decline over the medium term, albeit more slowly than in the baseline scenario, to approximately 122 percent of GDP by FY 2008/09.

Jamaica: Medium-Term Scenarios (In percent of GDP, unless otherwise indicated)

\begin{tabular}{|c|c|c|c|c|c|}
\hline & $2004 / 05$ & $2005 / 06$ & $2006 / 07$ & $2007 / 08$ & $2008 / 09$ \\
\hline & \multicolumn{5}{|c|}{ I. Baseline 1/ } \\
\hline Real GDP (in percent) & 0.7 & 3.7 & 3.0 & 3.5 & 3.5 \\
\hline Budget balance & -5.0 & 0.0 & 0.0 & 1.4 & 2.9 \\
\hline Of which: primary balance & 11.8 & 13.6 & 13.3 & 13.5 & 14.0 \\
\hline Off-budget expenditure & 2.2 & 2.5 & 2.5 & 1.7 & 1.6 \\
\hline Public debt & 138.6 & 126.1 & 118.2 & 109.7 & 100.5 \\
\hline Of which: government guaranteed debt & 7.3 & 6.8 & 6.4 & 6.1 & 5.8 \\
\hline \multirow[t]{2}{*}{$\begin{array}{l}\text { Six-month treasury bill rate (in percent per annum, } \\
\text { end of period) }\end{array}$} & 13.5 & 13.0 & 11.5 & 10.8 & 10.0 \\
\hline & \multicolumn{5}{|c|}{ II. Alternative } \\
\hline Real GDP (in percent) & 0.7 & 2.5 & 2.5 & 2.5 & 2.5 \\
\hline Budget balance & -5.0 & -2.1 & -3.2 & -3.0 & -3.0 \\
\hline Of which: primary balance & 11.8 & 11.7 & 11.2 & 11.2 & 11.2 \\
\hline Off-budget expenditure & 2.2 & 3.2 & 3.0 & 2.4 & 2.5 \\
\hline Public debt & 138.6 & 130.7 & 127.0 & 124.4 & 122.3 \\
\hline Of which: government guaranteed debt & 7.3 & 7.3 & 7.3 & 7.3 & 7.3 \\
\hline $\begin{array}{l}\text { Six-month treasury bill rate (in percent per annum, } \\
\text { end of period) }\end{array}$ & 13.5 & 13.0 & 13.0 & 13.0 & 13.0 \\
\hline Memorandum item: & & & & & \\
\hline Twelve-month inflation (in percent, end of period) & 13.2 & 9.5 & 7.0 & 6.0 & 6.0 \\
\hline
\end{tabular}

Sources: Jamaican authorities; and Fund staff estimates and projections.

1/ The baseline scenario assumes full implementation of the authorities' fiscal adjustment plans, whereas the alternative scenario reflects an unchanged primary balance from FY 2004/05 before grants and less favorable growth and interest rate assumptions.

\section{However, stress-testing these scenarios for major macroeconomic shocks} highlights the vulnerability of the Jamaican economy even under the relatively benign baseline assumptions. As highlighted by standard debt sustainability analysis (Table 8), the debt dynamics would considerably worsen in relation to the baseline under a variety of scenarios in which key economic variables are subject to adverse shocks. The dynamics is particularly sensitive to exchange rate and interest rate shocks, in reflection of the large 
share - about three-fourths - of foreign currency and floating rate debts in total public debt. ${ }^{14}$ For example, stress tests indicate that the public debt ratio could rise to over 160 percent of GDP over the next two years if either the real interest rate climbs two standard deviations above its historical average in FY 2005/06 and FY 2006/07, or a one time 30 percent real depreciation occurs in FY 2005/06.

\section{Staff Assessment}

21. The authorities have succeeded for the second consecutive fiscal year in maintaining stability following the near crisis in the first half of $\mathbf{2 0 0 3}$. Domestic interest rates have declined sharply from their March 2003 peak, the exchange rate has stabilized, and inflation has decelerated markedly. In FY 2004/05, the economy showed resilience in the face of severe adverse external shocks, including Hurricane Ivan and high oil prices. While favorable global liquidity conditions have been an important factor, these results also owe much to commitment to the renewed fiscal consolidation since mid-2003, reflected in very high primary budget surpluses. A key factor for success thus far has been the high degree of national ownership, which has permitted, notably, continued adherence to an MOU on public wage restraint agreed in February 2004 between the government and the trade unions, and the initiation of a comprehensive tax reform. The staff also attaches importance to the government's establishment, in early 2004, of a medium-term social and economic policy framework, designed in close consultation with its International Development Partners (IDPs) — including intensified Fund surveillance of the economic strategy.

\section{Meeting the government's balanced budget target for FY 2005/06, which is of} landmark importance for Jamaica's strategy to reduce the debt burden, will require determined control over expenditures and full implementation of tax reforms. The government's target, which is supported by the staff, appears within reach. The reduction in the interest burden, as well as wage restraint through the MOU, will help contain the expenditure side of the budget. On the revenue side, the authorities have taken an important step by implementing the first stage of the tax reform in a manner that produces a significant net resource gain for the budget. To ensure achievement of the fiscal targets, the authorities are encouraged to keep expenditure strictly within the budgeted levels and to pursue vigorously their efforts at improving tax administration and raising compliance with current tax liabilities.

\section{The authorities' medium-term economic strategy will remain subject to} important risks, both internal and external. Jamaica's exceptionally high public debt and its vulnerable structure - with three-fourths of total public debt in foreign currency or at floating interest rates - mean that even modest deviations from policy objectives could undermine confidence. Moreover, the Jamaican economy remains susceptible to changes in

${ }^{14}$ The scenarios underlying the debt sustainability analysis assume that the external debt is rolled over while fiscal surpluses are used to pay down domestic debt. As a result, the share of foreign currency and floating rate debt declines to about 60 percent of total public debt by FY 2008/09. 
the external environment, which has thus far been very favorable, and natural disasters will continue to be a major source of vulnerability. Against this background, successful implementation of the authorities' program for FY 2005/06 is key for consolidating macroeconomic stability, enhancing policy credibility, and bolstering the economy's resilience to shocks. Following the significant gains made over the past two years, the current year's program needs to reinforce and further consolidate those gains, and to place the Jamaican economy on a path of sustained and credible debt reduction over the medium term.

24. The envisaged reduction in the public debt-GDP ratio to 100 percent over the next four years will be challenging and demand sustained fiscal discipline, and the authorities' commitment to take the steps to meet their objectives is welcome. In the budget area, exceptional restraint will be needed to sustain the required primary surpluses in excess of 13 percent of GDP. The government will have to devise policies during the current fiscal year to keep the wage bill under control following the expiration of the MOU in FY 2006/07. Realizing significant expenditure savings in this area will be challenging as it may require a carefully planned restructuring of the civil service. Other current expenditure will have to be reduced further in relation to GDP in coming years, and the room for expansion in capital outlays will remain modest. Efforts for improving tax administration will have to be sustained to reduce evasion and support revenue growth broadly in line with that of GDP. Off-budget expenditure under the deferred financing scheme should be eliminated as planned in FY 2006/07.

25. Adjustment and restructuring efforts will be needed in the public entities, whose financial weaknesses prevented a sharper decline in the public debt in the last two years. The staff therefore welcomes the recent review of water tariffs and the new mechanism in place to review these tariffs annually to help strengthen the financial position of the National Water Commission. The authorities are encouraged to fully implement the planned downsizing of Air Jamaica and related cost-cutting measures while capping the subsidy the airline will continue to receive. As is appropriate, this is now being recognized explicitly in the budget. The staff stresses the need to strengthen fiscal procedures in the public sector with a view to fully incorporating in the budget, ex ante, any decisions to provide government support to public entities. Moreover, the granting of debt guarantees to such entities must be avoided to the extent possible. The authorities are encouraged to consider participating in a fiscal ROSC with a view to identifying procedural and institutional enhancements in support of their fiscal policy objectives.

26. The authorities are encouraged to continue to review, in consultation with the IDPs, the scope for a more proactive role of fiscal policy in support of the Millennium Development Goals. In particular, there may be scope for efficiency gains on the expenditure side to make more room for social spending. Such a reallocation would have to be supported by gains in addressing the crime problem, which the mission understands hinders not only private investment, but also the delivery of basic government services at the community level.

27. In the monetary policy area, the staff believes that the reductions in interest rates implemented in FY 2004/05 were appropriate, but caution is advised with respect to further easing. Lower interest rates turned out to be consistent with the targeted growth in base money. They also contributed to containing the budget deficit and central bank losses. 
However, with inflation still above international levels and prospects of global interest rate hikes, the mission advises caution with respect to the pace of further reductions in policy interest rates. ${ }^{15}$

\section{The staff believes that the current level of the exchange rate is broadly}

appropriate. The reduction in policy interest rates and the build-up of official reserves have maintained exchange rate stability, thereby limiting the real appreciation of the currency, which has been warranted on competitiveness grounds. Looking ahead, the staff welcomes the authorities' indication that, were there to be pressures in the foreign exchange market, for example due to tighter global liquidity conditions, they would keep intervention to a minimum and implement a balanced response comprising interest rate action and exchange rate flexibility. Over the medium term, the modest build-up in international reserves envisaged by the authorities appears to be justified, notwithstanding the high sterilization cost. The uneven and heavy external debt payment profile and the need for safeguarding against exogenous shocks, to which Jamaica is highly vulnerable, suggest a reserve cushion is warranted.

29. The staff welcomes the continuing progress towards strengthening the regulatory and supervisory framework of the financial system. In this context, the steps taken recently to reduce vulnerabilities in the securities industry and to strengthen the AML/CFT framework are particularly noteworthy. However, the securities industry remains highly exposed to interest rate and liquidity risks, and the authorities are therefore encouraged to take maximum advantage of the upcoming FSAP exercise to identify ways to address this vulnerability.

15 The mission's projections indicate that maintenance of real interest rates somewhat higher than those assumed in the authorities' macroeconomic framework would not in itself prevent achievement of the envisaged debt reduction to 100 percent of GDP by FY 2008/09. 
Figure 1. Jamaica: Selected Macroeconomic Indicators, FY 2001/02-FY2004/05
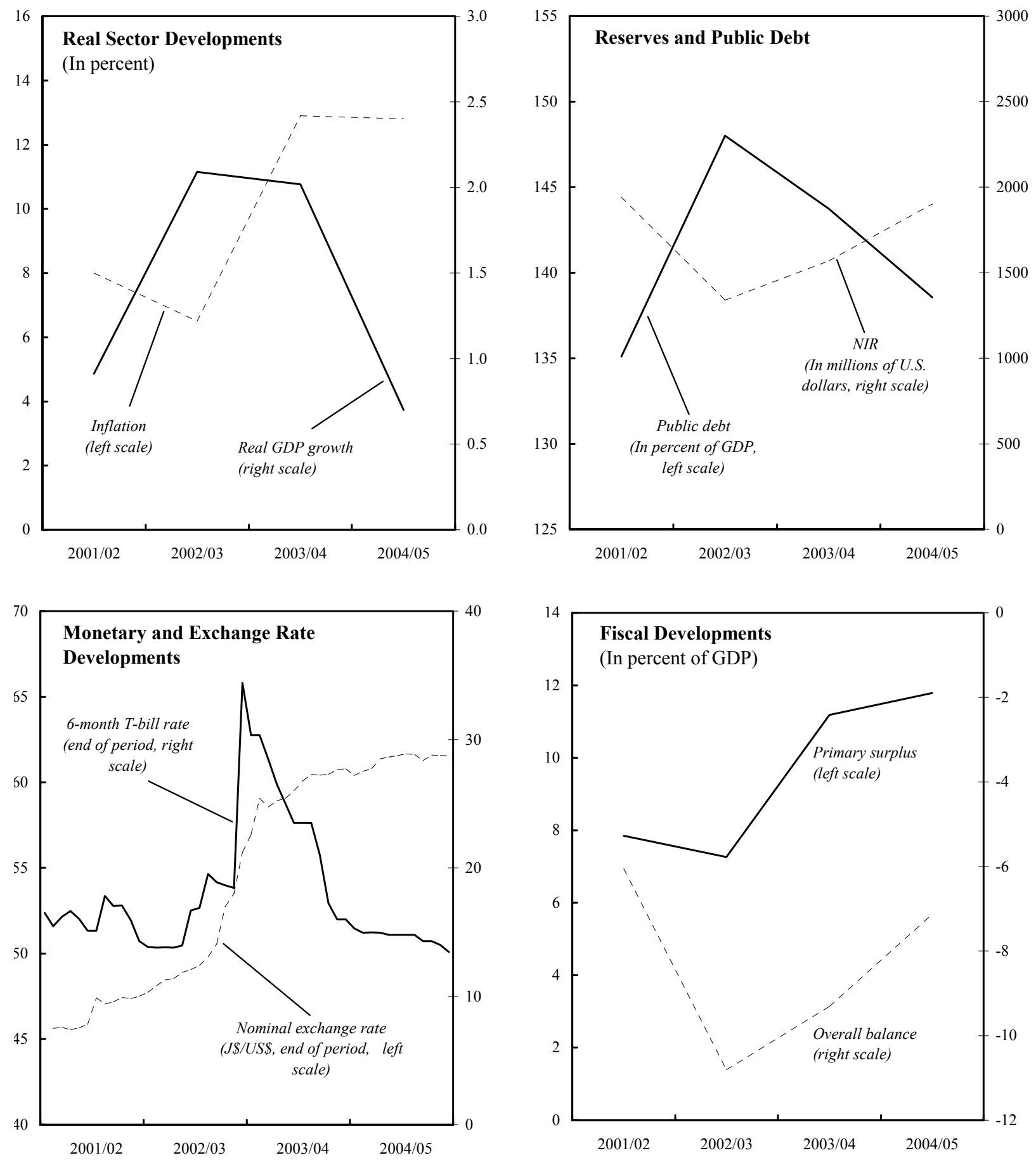

Sources: Jamaican authorities; and Fund staff estimates. 
Table 1. Jamaica: Selected Economic Indicators 1/

\begin{tabular}{|c|c|c|c|c|c|c|c|c|c|}
\hline & \multirow[b]{2}{*}{$2001 / 02$} & \multirow[b]{2}{*}{$2002 / 03$} & \multirow[b]{2}{*}{$2003 / 04$} & \multirow{2}{*}{$\begin{array}{r}\text { Prog. } \\
2004 / 05\end{array}$} & \multirow{2}{*}{$\begin{array}{r}\text { Prel. } \\
2004 / 05\end{array}$} & \multicolumn{4}{|c|}{ Projections } \\
\hline & & & & & & $2005 / 06$ & $2006 / 07$ & $2007 / 08$ & $2008 / 09$ \\
\hline & & & & (Annual $\mathrm{p}$ & percentage & changes) & & & \\
\hline \multicolumn{10}{|l|}{ GDP, prices, and employment } \\
\hline Real GDP & 0.9 & 2.1 & 2.0 & 2.5 & 0.7 & 3.7 & 3.0 & 3.5 & 3.5 \\
\hline Nominal GDP & 9.5 & 10.0 & 18.6 & 14.2 & 11.8 & 16.1 & 11.6 & 10.0 & 9.7 \\
\hline Consumer price index (end of period) & 7.6 & 6.2 & 16.8 & 9.9 & 13.2 & 9.5 & 7.0 & 6.0 & 6.0 \\
\hline Consumer price index (average) & 8.0 & 6.5 & 12.9 & 11.5 & 12.8 & 12.5 & 8.1 & 6.5 & 6.0 \\
\hline Exchange rate (end of period, in J\$/US\$) & 4.0 & 18.2 & 8.1 & $\ldots$ & 1.1 & $\ldots$ & $\ldots$ & $\ldots$ & $\ldots$ \\
\hline End-of-period REER (percent change, depreciation + ) & -3.9 & 14.3 & -4.2 & $\ldots$ & $\ldots$ & $\ldots$ & $\ldots$ & $\ldots$ & $\ldots$ \\
\hline Unemployment rate (in percent) & 14.8 & 15.4 & 12.8 & $\cdots$ & $\cdots$ & $\cdots$ & $\cdots$ & $\cdots$ & $\ldots$ \\
\hline & \multicolumn{9}{|c|}{ (In percent of GDP, unless otherwise indicated) } \\
\hline Government operations & & & & & & & & & \\
\hline Budgetary revenue & 27.0 & 28.1 & 29.4 & 31.8 & 30.9 & 31.2 & 30.4 & 30.1 & 29.9 \\
\hline Budgetary expenditure & 32.6 & 35.7 & 36.0 & 35.2 & 35.9 & 31.2 & 30.4 & 28.7 & 27.0 \\
\hline Primary expenditure & 19.2 & 20.8 & 18.2 & 17.9 & 19.1 & 17.6 & 17.1 & 16.6 & 15.9 \\
\hline Interest payments & 13.4 & 14.9 & 17.8 & 17.3 & 16.7 & 13.6 & 13.3 & 12.1 & 11.1 \\
\hline Budget balance & -5.6 & -7.6 & -6.6 & -3.5 & -5.0 & 0.0 & 0.0 & 1.4 & 2.9 \\
\hline Of which: primary balance & 7.8 & 7.3 & 11.2 & 13.8 & 11.8 & 13.6 & 13.3 & 13.5 & 14.0 \\
\hline Off-budget expenditure 2/ & 0.5 & 3.2 & 3.1 & 3.0 & 2.2 & 2.5 & 2.5 & 1.7 & 1.7 \\
\hline Overall fiscal balance & -6.1 & -10.8 & -9.7 & -6.5 & -7.1 & -2.5 & -2.5 & -0.3 & 1.3 \\
\hline Public debt & 135.1 & 148.0 & 143.7 & 136.4 & 138.6 & 126.1 & 118.2 & 109.8 & 100.6 \\
\hline \multicolumn{10}{|l|}{ External sector } \\
\hline Current account balance & -9.6 & -15.2 & -6.8 & -13.2 & -8.5 & -8.9 & -11.0 & -7.8 & -4.4 \\
\hline Of which: exports of goods, f.o.b. & 17.8 & 17.2 & 17.7 & 17.4 & 17.6 & 17.2 & 16.2 & 16.8 & 17.5 \\
\hline Of which: imports of goods, f.o.b. & 37.6 & 43.8 & 39.7 & 41.0 & 40.3 & 39.9 & 40.9 & 38.6 & 36.0 \\
\hline Of which: tourism services, net & 11.7 & 12.9 & 13.8 & 13.6 & 13.2 & 13.0 & 13.3 & 13.7 & 14.1 \\
\hline Net international reserves (in millions of US\$) & 1,942 & 1,340 & 1,569 & 1,400 & 1,902 & 2,000 & 2,046 & 2,228 & 2,311 \\
\hline \multicolumn{10}{|c|}{ (Changes in percent of beginning-of-period broad money) } \\
\hline Money and credit & & & & & & & & & \\
\hline Net foreign assets 3 / & 24.3 & -8.1 & 9.0 & -2.9 & 7.5 & 9.4 & 6.6 & 8.0 & 5.3 \\
\hline Net domestic assets & -14.3 & 15.6 & 11.3 & 17.0 & 2.7 & 6.0 & 4.7 & 2.0 & 4.4 \\
\hline Of which: credit to the central government & 71.2 & 8.2 & 9.7 & 10.0 & 0.5 & 7.1 & 5.6 & 3.0 & 1.0 \\
\hline Broad money & 10.0 & 7.5 & 20.2 & 14.1 & 10.3 & 15.4 & 11.3 & 9.9 & 9.7 \\
\hline $\begin{array}{l}\text { Interest rate (180-day BoJ CD rate, end of period, } \\
\text { in percent per annum) } 4 /\end{array}$ & 13.8 & 33.5 & 16.0 & 15.0 & 13.5 & 13.0 & 11.5 & 10.8 & 10.0 \\
\hline Velocity (ratio of GDP to broad money) & 2.6 & 2.7 & 2.6 & 2.6 & 2.6 & 2.6 & 2.7 & 2.7 & 2.7 \\
\hline Memorandum items: & & & & & & & & & \\
\hline Nominal GDP (in billions of Jamaica dollars) & 379.8 & 417.7 & 495.5 & 556.2 & 554.0 & 642.9 & 717.8 & 789.9 & 866.6 \\
\hline Exchange rate (end of period, J\$/US\$) & 47.6 & 56.2 & 60.8 & $\ldots$ & 61.5 & $\ldots$ & $\ldots$ & $\ldots$ & $\ldots$ \\
\hline
\end{tabular}

Sources: Jamaican authorities; and Fund staff estimates and projections.

1/ Based partly on assumptions provided by the authorities. Fiscal years run from April 1 to March 31 .

2/ Includes issuance of debt to the BoJ to cover its cash losses and related capitalized interest, and assumption of debt related to off-budget projects financed initially by the private sector.

3/ Including valuation adjustments.

4/ This rate is tracked very closely by the six-month Treasury bill yield, which is the benchmark for indexing variable rate debt instruments that account for a major part of the government domestic debt. 
Table 2. Jamaica: Summary of Central Government Operations

\begin{tabular}{|c|c|c|c|c|c|c|c|c|c|}
\hline & \multirow[b]{2}{*}{$2001 / 02$} & \multirow[b]{2}{*}{$2002 / 03$} & \multirow[b]{2}{*}{$2003 / 04$} & \multirow{2}{*}{$\begin{array}{r}\text { Prog. } \\
2004 / 05\end{array}$} & \multirow{2}{*}{$\begin{array}{r}\text { Prel. } \\
2004 / 05\end{array}$} & \multicolumn{4}{|c|}{ Projections 3/ } \\
\hline & & & & & & $2005 / 06$ & $2006 / 07$ & $2007 / 08$ & $2008 / 09$ \\
\hline & & \multicolumn{8}{|c|}{ (In billions of Jamaican dollars) } \\
\hline Budgetary revenue and grants & 102.6 & 117.2 & 145.5 & 176.6 & 171.3 & 200.6 & 218.1 & 237.6 & 259.5 \\
\hline Tax & 92.8 & 104.7 & 133.2 & 160.5 & 153.0 & 180.8 & 202.7 & 223.1 & 243.5 \\
\hline Nontax & 7.8 & 11.6 & 11.7 & 11.8 & 14.4 & 15.6 & 14.0 & 13.8 & 15.1 \\
\hline Grants & 2.0 & 0.9 & 0.6 & 4.3 & 4.0 & 4.2 & 1.4 & 0.8 & 0.9 \\
\hline Budgetary expenditure & 123.8 & 149.0 & 178.3 & 195.9 & 198.8 & 200.6 & 218.2 & 226.4 & 234.0 \\
\hline Primary expenditure & 72.8 & 86.9 & 90.1 & 99.7 & 106.0 & 113.1 & 122.8 & 130.8 & 137.9 \\
\hline Wage and salaries & 42.6 & 51.5 & 60.5 & 63.0 & 63.5 & 61.4 & 68.2 & 71.9 & 75.4 \\
\hline Of which: statutory arrears & $\ldots$ & $\ldots$ & $\ldots$ & 3.6 & 3.6 & $\ldots$ & $\ldots$ & $\ldots$ & $\ldots$ \\
\hline Other expenditure & 20.1 & 27.5 & 24.6 & 28.2 & 32.1 & 38.2 & 41.6 & 44.2 & 46.8 \\
\hline Capital expenditure & 10.1 & 7.9 & 5.0 & 8.5 & 10.4 & 13.4 & 13.0 & 14.7 & 15.7 \\
\hline Interest & 51.0 & 62.1 & 88.2 & 96.2 & 92.8 & 87.6 & 95.3 & 95.6 & 96.1 \\
\hline Domestic & 40.4 & 46.9 & 71.5 & 75.2 & 72.6 & 64.4 & 70.6 & 69.8 & 67.7 \\
\hline External & 10.7 & 15.2 & 16.7 & 21.0 & 20.1 & 23.2 & 24.8 & 25.8 & 28.5 \\
\hline Budget balance & -21.2 & -31.8 & -32.8 & -19.3 & -27.5 & 0.0 & $\mathbf{0 . 0}$ & 11.3 & 25.5 \\
\hline Of which: primary balance & 29.8 & 30.3 & 55.4 & 76.9 & 65.3 & 87.6 & 95.3 & 106.8 & 121.6 \\
\hline Off-budget expenditure & 1.8 & 13.4 & 15.3 & 16.9 & 12.0 & 16.1 & 17.9 & 13.7 & 14.3 \\
\hline Issuance of debt to the BoJ 1/ & -- & 11.5 & 11.5 & 14.9 & 8.2 & 16.1 & 16.2 & 13.7 & 14.3 \\
\hline Operating losses & 6.3 & 8.3 & 8.3 & 8.1 & 5.5 & 10.0 & 8.9 & 7.2 & 6.3 \\
\hline Accrued interest & -- & 3.3 & 3.3 & 6.8 & 2.6 & 6.1 & 7.3 & 6.5 & 8.1 \\
\hline Deferred financing $2 /$ & 1.4 & 1.4 & 3.8 & 2.0 & 3.9 & 0.0 & 1.7 & 0.0 & 0.0 \\
\hline Overall balance & -23.0 & -45.1 & -48.1 & -36.2 & -39.5 & -16.1 & -17.9 & -2.5 & 11.2 \\
\hline Financing & 23.0 & 45.1 & 48.1 & 36.2 & 39.5 & 16.1 & 17.9 & 2.5 & -11.2 \\
\hline External financing & 25.9 & -12.9 & 11.5 & 1.7 & 7.8 & 3.2 & 2.0 & 1.4 & 1.4 \\
\hline Domestic financing & -2.9 & 58.1 & 36.6 & 34.6 & 31.7 & 12.9 & 15.9 & 1.1 & -12.6 \\
\hline Banking system & 28.9 & 12.1 & 19.1 & 19.0 & 13.4 & 14.8 & 16.1 & 8.5 & 3.3 \\
\hline \multirow[t]{2}{*}{ Others } & -31.8 & 45.9 & 17.5 & 15.6 & 18.3 & -1.9 & -0.2 & -7.5 & -15.9 \\
\hline & & \multicolumn{8}{|c|}{ (In percent of GDP) } \\
\hline Budgetary revenue and grants & 27.0 & 28.1 & 29.4 & 31.8 & 30.9 & 31.2 & 30.4 & 30.1 & 29.9 \\
\hline Tax & 24.4 & 25.1 & 26.9 & 28.8 & 27.6 & 28.1 & 28.2 & 28.2 & 28.1 \\
\hline Nontax & 2.1 & 2.8 & 2.4 & 2.1 & 2.6 & 2.4 & 2.0 & 1.7 & 1.7 \\
\hline Grants & 0.5 & 0.2 & 0.1 & 0.8 & 0.7 & 0.7 & 0.2 & 0.1 & 0.1 \\
\hline Budgetary expenditure & 32.6 & 35.7 & 36.0 & 35.2 & 35.9 & 31.2 & 30.4 & 28.7 & 27.0 \\
\hline Primary expenditure & 19.2 & 20.8 & 18.2 & 17.9 & 19.1 & 17.6 & 17.1 & 16.6 & 15.9 \\
\hline Wage and salaries & 11.2 & 12.3 & 12.2 & 11.3 & 11.5 & 9.5 & 9.5 & 9.1 & 8.7 \\
\hline Other expenditure & 5.3 & 6.6 & 5.0 & 5.1 & 5.8 & 5.9 & 5.8 & 5.6 & 5.4 \\
\hline Capital expenditure & 2.7 & 1.9 & 1.0 & 1.5 & 1.9 & 2.1 & 1.8 & 1.9 & 1.8 \\
\hline Interest & 13.4 & 14.9 & 17.8 & 17.3 & 16.7 & 13.6 & 13.3 & 12.1 & 11.1 \\
\hline Domestic & 10.6 & 11.2 & 14.4 & 13.5 & 13.1 & 10.0 & 9.8 & 8.8 & 7.8 \\
\hline External & 2.8 & 3.6 & 3.4 & 3.8 & 3.6 & 3.6 & 3.4 & 3.3 & 3.3 \\
\hline Budget balance & -5.6 & -7.6 & -6.6 & -3.5 & -5.0 & 0.0 & $\mathbf{0 . 0}$ & 1.4 & 2.9 \\
\hline Of which: primary balance & 7.8 & 7.3 & 11.2 & 13.8 & 11.8 & 13.6 & 13.3 & 13.5 & 14.0 \\
\hline Off-budget expenditure & 0.5 & 3.2 & 3.1 & 3.0 & 2.2 & 2.5 & 2.5 & 1.7 & 1.7 \\
\hline Issuance of debt to the BoJ 1/ & -- & 2.8 & 2.3 & 2.7 & 1.5 & 2.5 & 2.3 & 1.7 & 1.7 \\
\hline Deferred financing $2 /$ & 0.5 & 0.4 & 0.8 & 0.4 & 0.7 & 0.0 & 0.2 & 0.0 & 0.0 \\
\hline Overall balance & -6.1 & -10.8 & -9.7 & -6.5 & -7.1 & -2.5 & -2.5 & -0.3 & 1.3 \\
\hline Budgetary principal payment & 23.9 & 21.5 & 20.0 & 23.9 & 23.9 & 21.5 & 20.2 & 18.3 & 23.7 \\
\hline Domestic & 20.4 & 12.9 & 16.5 & 18.6 & 18.6 & 16.6 & 18.1 & 14.3 & 18.9 \\
\hline External & 3.6 & 8.6 & 3.5 & 5.3 & 5.3 & 4.9 & 2.2 & 4.0 & 4.7 \\
\hline \multicolumn{10}{|l|}{ Memorandum items: } \\
\hline Primary balance excluding grants (percent of GDP) & 7.8 & 7.3 & 11.2 & 13.8 & 11.8 & 13.6 & 13.3 & 13.5 & 14.0 \\
\hline Interest expenditure net of interest tax (percent of GDP) & 11.2 & 12.7 & 14.8 & 14.6 & 14.0 & 11.2 & 10.9 & 9.8 & 8.9 \\
\hline Overall balance of public enterprises & 0.5 & 1.1 & 1.3 & 0.9 & 0.7 & 0.7 & 1.0 & 1.0 & 1.0 \\
\hline Public sector overall balance & -5.5 & -9.7 & -8.4 & -6.5 & -6.5 & -1.8 & -1.5 & 0.7 & 2.3 \\
\hline Public debt & 135.1 & 148.0 & 143.7 & 136.4 & 138.6 & 126.1 & 118.2 & 109.8 & 100.6 \\
\hline Gross financing (in percent of GDP) & $\ldots$ & $\ldots$ & 27.7 & 52.2 & 31.2 & 24.0 & 22.7 & 18.6 & 22.4 \\
\hline GDP (in billions of J\$) & 379.8 & 417.7 & 495.5 & 556.2 & 554.0 & 642.9 & 717.8 & 789.9 & 866.6 \\
\hline
\end{tabular}

Sources: Jamaican authorities; Fund staff estimates and projections.

$1 /$ Refers to debt issued in relation to central bank losses.

2/ Debt issued upon assuming public investment projects carried out by the private sector.

3/ The starting point for the projections is the staff projection for FY 2005/06. 
Table 3. Jamaica: Summary of the Public Debt

\begin{tabular}{|c|c|c|c|c|c|c|c|c|}
\hline & \multirow[b]{2}{*}{$2001 / 02$} & \multirow[b]{2}{*}{$2002 / 03$} & \multirow[b]{2}{*}{$2003 / 04$} & \multirow{2}{*}{$\begin{array}{r}\text { Prel. } \\
2004 / 05\end{array}$} & \multicolumn{4}{|c|}{ Projections } \\
\hline & & & & & $2005 / 06$ & $2006 / 07$ & $2007 / 08$ & $2008 / 09$ \\
\hline & & \multicolumn{7}{|c|}{ (In billions of Jamaican dollars) } \\
\hline \multicolumn{9}{|l|}{ Debt stock } \\
\hline Public debt & 513 & 618 & 712 & 768 & 811 & 849 & 867 & 872 \\
\hline Government debt & 491 & 588 & 677 & 727 & 767 & 803 & 819 & 822 \\
\hline Domestic & 300 & 366 & 418 & 449 & 467 & 487 & 492 & 482 \\
\hline Of which: US\$ linked & 60 & 73 & 97 & 85 & 90 & 94 & 98 & 101 \\
\hline External & 191 & 222 & 259 & 278 & 300 & 315 & 327 & 340 \\
\hline Concessional & 94 & 112 & 113 & 103 & 97 & 88 & 76 & 64 \\
\hline Commercial & 86 & 110 & 146 & 175 & 203 & 227 & 251 & 276 \\
\hline Government guaranteed debt & 22 & 30 & 35 & 41 & 44 & 46 & 48 & 50 \\
\hline External & 15 & 21 & 27 & 32 & 34 & 36 & 37 & 38 \\
\hline Domestic & 7 & 9 & 9 & 8 & 10 & 10 & 11 & 12 \\
\hline Domestic currency debt & 248 & 302 & 329 & 373 & 387 & 403 & 405 & 393 \\
\hline Foreign currency debt & 206 & 244 & 286 & 310 & 334 & 351 & 364 & 378 \\
\hline US\$ linked debt & 60 & 73 & 97 & 85 & 90 & 94 & 98 & 101 \\
\hline & & \multicolumn{7}{|c|}{ (In percent of GDP) } \\
\hline Public debt & 135.1 & 148.0 & 143.7 & 138.6 & 126.1 & 118.2 & 109.8 & 100.6 \\
\hline Government debt & 129.2 & 140.8 & 136.6 & 131.2 & 119.3 & 111.8 & 103.7 & 94.9 \\
\hline Domestic & 79.0 & 87.6 & 84.3 & 81.0 & 72.7 & 67.9 & 62.2 & 55.7 \\
\hline Of which: US\$ linked & 15.7 & 17.5 & 19.5 & 15.3 & 14.1 & 13.2 & 12.4 & 11.6 \\
\hline External & 14.5 & 53.2 & 52.3 & 50.2 & 46.6 & 43.9 & 41.4 & 39.2 \\
\hline Concessional & 44.8 & 26.9 & 22.8 & 18.6 & 15.1 & 12.2 & 9.6 & 7.4 \\
\hline Commercial & 4.7 & 26.3 & 29.5 & 31.5 & 31.5 & 31.7 & 31.8 & 31.8 \\
\hline Government guaranteed debt & 15.7 & 7.2 & 7.2 & 7.3 & 6.8 & 6.4 & 6.1 & 5.8 \\
\hline Domestic currency debt & 65.2 & 72.2 & 66.5 & 67.3 & 60.1 & 56.2 & 51.3 & 45.3 \\
\hline Foreign currency debt & 51.2 & 58.3 & 57.7 & 56.0 & 52.0 & 48.9 & 46.1 & 43.7 \\
\hline US\$ linked debt & 15.7 & 17.5 & 19.5 & 15.3 & 14.1 & 13.2 & 12.4 & 11.6 \\
\hline \multicolumn{9}{|l|}{ Memorandum items: } \\
\hline Net debt (in billions of J\$) & 480 & 596 & 690 & 747 & 790 & 828 & 846 & 852 \\
\hline In percent of GDP & 126.3 & 142.7 & 139.3 & 134.8 & 122.9 & 115.4 & 107.1 & 98.3 \\
\hline Gross debt held by the market (in percent of GDP) & 84.3 & 94.9 & 100.0 & 99.3 & 92.3 & 88.6 & 84.0 & 78.6 \\
\hline Domestic currency & 43.4 & 51.9 & 52.0 & 53.2 & 47.5 & 44.4 & 40.4 & 35.7 \\
\hline Foreign currency or US\$ linked & 40.9 & 43.0 & 48.0 & 46.1 & 44.9 & 44.2 & 43.5 & 42.9 \\
\hline Total debt (in billions of US\$) & 10.5 & 11.0 & 11.7 & 12.5 & 12.4 & 12.4 & 12.2 & 11.9 \\
\hline Of which: foreign currency debt & 4.1 & 4.3 & 4.7 & 5.0 & 5.1 & 5.1 & 5.1 & 5.2 \\
\hline GDP (in billions of J\$) & 380 & 418 & 495 & 554 & 643 & 718 & 790 & 867 \\
\hline
\end{tabular}

Sources: Jamaican authorities; and Fund staff estimates and projections.

1/ Authorities' program, originally projected for FY 2004/05, as reported in IMF Country Report No. 04/263.

2/ Revised projections for FY 2004/05, as reported in IMF Country Report No. 05/61. 
Table 4. Jamaica: Summary Balance of Payments (In millions of U.S. dollars)

\begin{tabular}{|c|c|c|c|c|c|c|c|c|c|}
\hline & \multirow[b]{2}{*}{$2001 / 02$} & \multirow[b]{2}{*}{$2002 / 03$} & \multirow[b]{2}{*}{ 2003/04 } & \multirow{2}{*}{$\begin{array}{r}\text { Prog. } \\
2004 / 05\end{array}$} & \multirow{2}{*}{$\begin{array}{r}\text { Prel. } \\
2004 / 05\end{array}$} & \multicolumn{4}{|c|}{ Projections } \\
\hline & & & & & & $2005 / 06$ & $2006 / 07$ & $2007 / 08$ & $2008 / 09$ \\
\hline Current account & -753 & $-1,160$ & -567 & $-1,178$ & -764 & -901 & $-1,177$ & -883 & -532 \\
\hline Trade balance & $-1,577$ & $-2,026$ & $-1,821$ & $-2,103$ & $-2,055$ & $-2,293$ & $-2,635$ & $-2,476$ & $-2,225$ \\
\hline Exports (f.o.b.) & 1,424 & 1,314 & 1,473 & 1,550 & 1,584 & 1,739 & 1,738 & 1,902 & 2,105 \\
\hline Imports (f.o.b.) & 3,001 & 3,340 & 3,294 & 3,653 & 3,640 & 4,032 & 4,373 & 4,377 & 4,330 \\
\hline Services (net) & 323 & 371 & 603 & 542 & 579 & 657 & 690 & 833 & 986 \\
\hline Transportation & -254 & -227 & -132 & -213 & -180 & -205 & -250 & -221 & -183 \\
\hline Travel & 956 & 986 & 1,145 & 1,214 & 1,188 & 1,315 & 1,419 & 1,557 & 1,697 \\
\hline Of which: tourism receipts & 1,166 & 1,248 & 1,401 & 1,481 & 1,470 & 1,612 & 1,730 & 1,884 & 2,040 \\
\hline Other services & -379 & -389 & -410 & -460 & -429 & -453 & -478 & -503 & -527 \\
\hline Income (net) & -457 & -613 & -584 & -832 & -660 & -720 & -694 & -751 & -833 \\
\hline Of which: investment income (net) & -531 & -696 & -658 & -912 & -757 & -824 & -805 & -870 & -961 \\
\hline Current transfers (net) & 958 & 1,109 & 1,234 & 1,215 & 1,373 & 1,455 & 1,462 & 1,510 & 1,539 \\
\hline Government (net) & 117 & 108 & 105 & 66 & 114 & 114 & 76 & 80 & 83 \\
\hline Private (net) & 842 & 1,000 & 1,129 & 1,150 & 1,259 & 1,340 & 1,386 & 1,431 & 1,456 \\
\hline Capital and financial account & 1,409 & 558 & 796 & 1,014 & 1,096 & 1,000 & 1,223 & 1,065 & 615 \\
\hline Capital account (net) & -24 & -12 & 1 & -18 & 3 & 3 & 2 & 2 & 2 \\
\hline Financial account (net) & 1,433 & 570 & 796 & 1,032 & 1,094 & 997 & 1,222 & 1,064 & 614 \\
\hline Direct investment (net) & 454 & 405 & 593 & 337 & 515 & 708 & 1,276 & 1,145 & 733 \\
\hline Official capital flows (net) & 590 & -227 & 143 & 147 & 175 & 50 & 30 & 20 & 20 \\
\hline Private flows (net) & 388 & 392 & 60 & 548 & 403 & 239 & -85 & -101 & -140 \\
\hline Portfolio investment (net) & -26 & -218 & -286 & -182 & -286 & -308 & -323 & -339 & -356 \\
\hline Other private inflows (net) & 415 & 610 & 346 & 730 & 689 & 547 & 239 & 238 & 217 \\
\hline Of which : unidentified flows & 2 & 159 & -49 & 0 & 541 & 0 & 0 & 0 & 0 \\
\hline Overall balance/change in NFA & 656 & -602 & 229 & -163 & 333 & 98 & 46 & 182 & 83 \\
\hline \multicolumn{10}{|l|}{ Memorandum items: } \\
\hline Net international reserves & 1,942 & 1,340 & 1,569 & 1,400 & 1,902 & 2,000 & 2,046 & 2,228 & 2,311 \\
\hline Current account (in percent of GDP) & -9.6 & -15.2 & -6.8 & -13.2 & -8.5 & -8.9 & -11.0 & -7.8 & -4.4 \\
\hline Exports (in percent of GDP) & 17.8 & 17.2 & 17.7 & 17.4 & 17.6 & 17.2 & 16.2 & 16.8 & 17.5 \\
\hline Imports (in percent of GDP) & 37.6 & 43.8 & 39.7 & 41.0 & 40.3 & 39.9 & 40.9 & 38.6 & 36.0 \\
\hline GDP (in millions of U.S. dollars) & 7,979 & 7,622 & 8,304 & 8,909 & 9,021 & 10,116 & 10,700 & 11,329 & 12,020 \\
\hline
\end{tabular}

Sources: Jamaican authorities; and Fund staff estimates. 
Table 5. Jamaica: Summary Accounts of the Bank of Jamaica 1/

\begin{tabular}{|c|c|c|c|c|c|c|c|c|c|}
\hline \multirow{2}{*}{ End-of-period stocks 1/ } & $2001 / 02$ & $2002 / 03$ & $2003 / 04$ & $\begin{array}{r}\text { Prog. } \\
2004 / 05\end{array}$ & $\begin{array}{r}\text { Prel. } \\
2004 / 05\end{array}$ & $2005 / 06$ & \multicolumn{2}{|c|}{ Projections } & $2008 / 09$ \\
\hline & \multicolumn{9}{|c|}{ (In billions of Jamaica dollars) } \\
\hline Net international reserves & 95 & 75 & 96 & 89 & 118 & 131 & 140 & 158 & 169 \\
\hline Net domestic assets & -65 & -43 & -59 & -48 & -76 & -83 & -87 & -99 & -105 \\
\hline Net claims on public sector $2 /$ & 37 & 64 & 76 & 93 & 95 & 111 & 125 & 139 & 151 \\
\hline Of which: central government & 41 & 57 & 68 & 84 & 78 & 94 & 110 & 124 & 138 \\
\hline Open market operations & -99 & -86 & -108 & -112 & -144 & -163 & -174 & -195 & -206 \\
\hline Of which: commercial banks & -29 & -17 & -25 & 25 & -34 & -54 & -62 & -74 & -91 \\
\hline Credit to commercial banks & -4 & -12 & -14 & -12 & -13 & -9 & -9 & -10 & -11 \\
\hline Net credit to nonbank financial institutions & -1 & -1 & -1 & -1 & -1 & -1 & -1 & -1 & -1 \\
\hline Other $3 /$ & 3 & -7 & -12 & -16 & -14 & -22 & -28 & -33 & -38 \\
\hline Monetary base & 30 & 32 & 36 & 42 & 42 & 48 & 53 & 59 & 65 \\
\hline Currency in circulation & 17 & 17 & 21 & 23 & 24 & 27 & 30 & 33 & 36 \\
\hline Liabilities to commercial banks & 13 & 15 & 16 & 19 & 18 & 21 & 23 & 26 & 28 \\
\hline \multicolumn{10}{|l|}{ Fiscal year flows 1/ } \\
\hline Net international reserves & 36.9 & -19.7 & 20.5 & -6.2 & 22.1 & 13.6 & 9.0 & 17.7 & 11.5 \\
\hline Net domestic assets & -37.1 & 22.0 & -16.8 & 11.8 & -16.7 & -7.2 & -3.6 & -12.4 & -5.8 \\
\hline Net claims on public sector $2 /$ & 4.7 & 27.2 & 11.9 & 17.7 & 19.3 & 16.2 & 13.7 & 14.3 & 11.9 \\
\hline Of which: central government & 26.2 & 15.9 & 11.5 & 16.4 & 9.3 & 16.1 & 16.2 & 13.7 & 14.3 \\
\hline Open market operations & -37.8 & 13.0 & -22.1 & -3.3 & -35.6 & -19.2 & -10.6 & -21.0 & -11.5 \\
\hline Of which: commercial banks & -37.7 & 12.5 & -8.4 & -0.2 & -59.3 & -20.0 & -7.9 & -12.4 & -17.0 \\
\hline Credit to commercial banks & 2.2 & -8.1 & -1.2 & 1.3 & 1.1 & 3.9 & -0.7 & -0.6 & -0.6 \\
\hline Net credit to nonbank financial institutions & -0.1 & 0.1 & 0.1 & 0.2 & -0.1 & -0.1 & -0.1 & -0.1 & -0.1 \\
\hline Other $3 /$ & -6.1 & -10.2 & -5.5 & -4.0 & -1.4 & -8.0 & -6.0 & -5.0 & -5.5 \\
\hline Monetary base & -0.3 & 2.3 & 3.7 & 5.6 & 5.5 & 6.4 & 5.4 & 5.3 & 5.7 \\
\hline Currency in circulation & 1 & -0.2 & 3.3 & 2.6 & 2.9 & 3.6 & 3.1 & 3.0 & 3.2 \\
\hline Liabilities to commercial banks & -1.8 & 2.4 & 0.4 & 3.0 & 2.5 & 2.8 & 2.4 & 2.3 & 2.5 \\
\hline & \multicolumn{9}{|c|}{ (Changes in percent of beginning-of-period monetary base) } \\
\hline Net international reserves & 121.0 & -65.3 & 63.1 & -17.2 & 61.1 & 32.6 & 18.8 & 33.0 & 19.6 \\
\hline Net domestic assets & -121.8 & 72.8 & -51.8 & 32.7 & -46.0 & -17.2 & -7.5 & -23.1 & -9.8 \\
\hline Net claims on public sector $2 /$ & 15.4 & 90.1 & 36.7 & 48.8 & 53.4 & 38.9 & 28.5 & 26.7 & 20.2 \\
\hline Open market operations & -123.9 & 43.0 & -67.9 & -9.2 & -98.3 & -46.1 & -22.1 & -39.3 & -19.5 \\
\hline Net credit to commercial banks & 7.2 & -26.8 & -3.7 & 3.7 & 3.0 & 9.3 & -1.4 & -1.1 & -1.0 \\
\hline Net credit to nonbank financial institutions & -0.4 & 0.2 & 0.2 & 0.4 & -0.3 & -0.1 & -0.2 & -0.1 & -0.1 \\
\hline Other $3 /$ & -20.1 & -33.7 & -17.0 & -11.1 & -3.8 & -19.1 & -12.4 & -9.3 & -9.3 \\
\hline Monetary base & -0.8 & 7.5 & 11.3 & 15.5 & 15.1 & 15.4 & 11.3 & 9.9 & 9.7 \\
\hline \multicolumn{10}{|l|}{ Memorandum items: } \\
\hline $\begin{array}{l}\text { Change in net claims on the central government } \\
\text { (percent of GDP) }\end{array}$ & 6.9 & 3.8 & 2.3 & 2.9 & 1.7 & 2.5 & 2.3 & 1.7 & 1.7 \\
\hline Exchange rate (end of period) & 47.6 & 56.1 & 60.9 & ? & $\ldots$ & & & $\ldots$ & \\
\hline NIR (in millions of U.S. dollars) & 1,942 & 1,339 & 1,569 & 1400 & 1,902 & 2,000 & 2,046 & 2,228 & 2,311 \\
\hline
\end{tabular}

Sources: Bank of Jamaica; and Fund staff estimates and projections.

1/ A fiscal year runs from April 1 to March 31.

2/ Includes Bank of Jamaica's losses.

3/ Includes medium- and long-term liabilities, valuation adjustments, and allocation of SDRs. 
Table 6. Jamaica: Summary Monetary Survey 1/

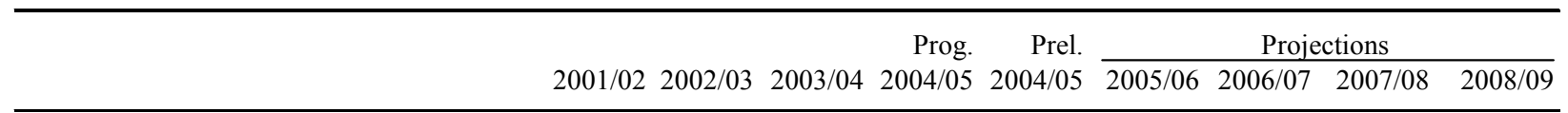

\section{End-of-period stocks 1/}

Net foreign assets

Net domestic assets

Net claims on public sector 2/

Of which: central government

Open market operations

Credit to private sector Of which: foreign currency

Other 3/

Liabilities to private sector (M3)

Money supply (M2)

Foreign currency deposits (FCD)

\section{Fiscal year flows 1/}

Net foreign assets

Net domestic assets

Net claims on public sector 2/

Of which: central government

Open market operations

Credit to private sector

Of which: foreign currency

Other 3/

Liabilities to private sector (M3)

Money supply (M2)

Foreign currency deposits (FCD)

Net foreign assets

Net domestic assets

Net claims on public sector 2/

Of which: central government

Open market operations

Credit to private sector

Of which: foreign currency

Other 3/

Liabilities to private sector (M3)

Memorandum items:

Dollarization (share of FCD in total deposits)

M3 velocity

(In billions of Jamaican dollars)

$\begin{array}{rrrrrrrrr}100 & 88 & 102 & 97 & 116 & 136 & 152 & 174 & 190 \\ 48 & 71 & 89 & 121 & 94 & 106 & 118 & 123 & 136 \\ 119 & 151 & 165 & 183 & 179 & 193 & 207 & 216 & 216 \\ 120 & 132 & 147 & 165 & 148 & 163 & 179 & 187 & 190 \\ -70 & -69 & -83 & -87 & -110 & -109 & -112 & -120 & -115 \\ 40 & 55 & 80 & 106 & 93 & 109 & 124 & 142 & 163 \\ 11 & 20 & 27 & 33 & 33 & 39 & 45 & 52 & 59 \\ -42 & -66 & -73 & -82 & -68 & -86 & -101 & -114 & -128 \\ 148 & 159 & 191 & 218 & 210 & 243 & 270 & 297 & 326 \\ 108 & 107 & 125 & 142 & 139 & 164 & 185 & 207 & 231 \\ 40 & 51 & 66 & 75 & 71 & 79 & 85 & 90 & 95\end{array}$

$\begin{array}{rrrrrrrrr}32.6 & -12.0 & 14.2 & -5.6 & 14.4 & 19.9 & 16.0 & 21.6 & 15.6 \\ -19.2 & 23.1 & 17.9 & 32.4 & 5.2 & 12.6 & 11.4 & 5.3 & 13.2 \\ 22.6 & 31.6 & 13.8 & 18.7 & 13.8 & 14.9 & 13.6 & 8.7 & 0.4 \\ 95.5 & 12.1 & 15.4 & 19.0 & 1.0 & 14.8 & 16.1 & 8.1 & 2.9 \\ -16.6 & 0.5 & -13.7 & -3.6 & -26.9 & 0.8 & -2.7 & -8.6 & 5.5 \\ 5.8 & 14.9 & 25.2 & 26.2 & 13.0 & 15.7 & 15.3 & 18.1 & 21.1 \\ 3.9 & 8.4 & 7.5 & 5.8 & 5.9 & 6.1 & 6.5 & 6.3 & 7.0 \\ -31.0 & -24.0 & -7.3 & -8.9 & 5.3 & -18.8 & -14.7 & -12.9 & -13.8 \\ & & & & & & & & \\ 13.5 & 11.0 & 32.1 & 26.8 & 22.6 & 29.4 & 27.5 & 28.4 & 28.2 \\ 6.9 & -0.5 & 17.4 & 17.4 & 15.4 & 19.4 & 18.1 & 18.7 & 18.5 \\ 6.5 & 11.6 & 14.6 & 9.4 & 7.1 & 10.1 & 9.4 & 9.7 & 9.6\end{array}$

(Changes in percent of beginning-of-period M3)

$\begin{array}{rrrrrrrrr}24.3 & -8.1 & 9.0 & -2.9 & 7.5 & 9.4 & 6.6 & 8.0 & 5.3 \\ -14.3 & 15.6 & 11.3 & 17.0 & 2.7 & 6.0 & 4.7 & 2.0 & 4.4 \\ 16.8 & 21.4 & 8.7 & 9.8 & 7.2 & 7.1 & 5.6 & 3.2 & 0.1 \\ 71.2 & 8.2 & 9.7 & 10.0 & 0.5 & 7.0 & 6.6 & 3.0 & 1.0 \\ -12.3 & 0.4 & -8.6 & -1.9 & -14.1 & 0.4 & -1.1 & -3.2 & 1.9 \\ 4.3 & 10.1 & 15.9 & 13.7 & 6.8 & 7.5 & 6.3 & 6.7 & 7.1 \\ 2.9 & 5.7 & 4.7 & 3.1 & 3.1 & 2.9 & 2.7 & 2.3 & 2.3 \\ -23.1 & -16.2 & -4.6 & -4.7 & 2.8 & -8.9 & -6.1 & -4.8 & -4.7 \\ 10.0 & 7.5 & 20.2 & 14.1 & 10.3 & 15.4 & 11.3 & 9.9 & 9.7\end{array}$

\begin{tabular}{rrrrrrrrr}
30.5 & 36.2 & 37.6 & 38.7 & 31.2 & 30.0 & 29.0 & 28.0 & 27.0 \\
2.6 & 2.6 & 2.6 & 2.6 & 2.6 & 2.6 & 2.7 & 2.7 & 2.7 \\
\hline
\end{tabular}

Sources: Bank of Jamaica; and Fund staff estimates and projections.

1/ A fiscal year runs from April 1 to March 31.

2/ Includes Bank of Jamaica's losses.

3/ Includes net credit to nonbank financial institutions, capital accounts, valuation adjustment, securities sold under repo and net unclassified assets 
Table 7. Jamaica: Selected Vulnerability Indicators

\begin{tabular}{|c|c|c|c|c|c|}
\hline & $2000 / 01$ & $2001 / 02$ & $2002 / 03$ & $2003 / 04$ & $2004 / 051 /$ \\
\hline \multicolumn{6}{|l|}{ Key economic and market indicators } \\
\hline Real GDP growth (in percent) & 1.1 & 0.9 & 2.1 & 2.0 & 0.7 \\
\hline CPI inflation (period average, in percent) & 7.7 & 8.0 & 6.5 & 12.9 & 12.8 \\
\hline Short-term (ST) interest rate (in percent) & 16.9 & 14.3 & 33.5 & 16.0 & 13.5 \\
\hline EMBI secondary market spread (bps, end of period) & $\ldots$ & 550 & 800 & 551 & 405 \\
\hline Exchange rate NC/US\$ (end of period) & 45.7 & 47.6 & 56.2 & 60.8 & 61.5 \\
\hline \multicolumn{6}{|l|}{ External sector } \\
\hline Exchange rate regime & & \multicolumn{4}{|c|}{ Managed float } \\
\hline Current account balance (percent of GDP) & -5.3 & -9.6 & -15.2 & -6.8 & -8.5 \\
\hline Net FDI inflows (percent of GDP) & 6.7 & 5.7 & 5.3 & 7.1 & 5.7 \\
\hline Exports (percentage change of US\$ value, GNFS) & 3.7 & -8.4 & 1.7 & 10.8 & 4.9 \\
\hline Real effective exchange rate $(1995 / 96=100 ;$ end of period $)$ & 141.4 & 142.8 & 142.5 & 122.3 & 129.4 \\
\hline Gross international reserves (GIR) in US\$ billion & 1.4 & 2.0 & 1.4 & 1.6 & 1.9 \\
\hline GIR in percent of ST debt at remaining maturity (RM) & 375.5 & 273.9 & 472.0 & 327.0 & 350.5 \\
\hline GIR in percent of ST debt at RM and banks' FX deposits. & 124.6 & 127.9 & 114.5 & 99.6 & 113.0 \\
\hline Net international reserves (NIR) in US\$ billion & 1.3 & 1.9 & 1.3 & 1.6 & 1.9 \\
\hline Total gross external debt (ED) in percent of GDP & 46.0 & 50.7 & 54.8 & 54.5 & 55.9 \\
\hline Total gross external debt in percent of exports of GNFS & 102.1 & 127.2 & 126.4 & 123.6 & 131.2 \\
\hline Gross external financing requirement (in US\$ billion) 2/ & 0.7 & 1.0 & 1.9 & 0.8 & 1.5 \\
\hline \multicolumn{6}{|l|}{ Public sector (PS) 3/ } \\
\hline Overall balance (percent of GDP) & -4.8 & -6.1 & -10.8 & -9.7 & -7.1 \\
\hline Primary balance (percent of GDP) & 11.2 & 7.8 & 7.3 & 11.2 & 11.8 \\
\hline Debt-stabilizing primary balance (percent of GDP) 4/ & 7.3 & 7.3 & 17.3 & 10.0 & 3.5 \\
\hline Gross PS financing requirement (in percent of GDP) $5 /$ & 19 & 30 & 32 & 33 & 31 \\
\hline Public sector gross debt (PSGD, in percent of GDP) & 132 & 132 & 146 & 143 & 138 \\
\hline Public sector net debt (in percent of GDP) & 126 & 126 & 141 & 138 & 135 \\
\hline \multicolumn{6}{|l|}{ Financial sector (FS) 9/ } \\
\hline Capital adequacy ratio (in percent) & 21.7 & 17.8 & 14.4 & 13.1 & 13.5 \\
\hline NPLs in percent of total loans & 9.6 & 8.0 & 4.9 & 3.9 & 3.6 \\
\hline Provisions in percent of NPLs & 116.8 & 126.5 & 117.9 & 117.1 & 118.2 \\
\hline Return on average assets (in percent) & 0.4 & 2.1 & 2.8 & 4.3 & 2.2 \\
\hline Return on equity (in percent) & 4.1 & 22.1 & 26.4 & 39.0 & 18.8 \\
\hline FX deposits held by residents (in percent of total deposits) & 24.0 & 28.0 & 30.1 & 32.0 & 31.2 \\
\hline FX loans to residents (in percent of total loans) & 21.5 & 28.1 & 35.7 & 33.8 & 35.5 \\
\hline Net open forex position (in percent of capital) $10 /$ & $\ldots$ & $\ldots$ & 20.9 & -8.2 & -8.2 \\
\hline Government debt held by FS ( percent of total FS assets) & 17.6 & 36.6 & 27.6 & 25.7 & 22.0 \\
\hline Credit to private sector (percent change) & 7.3 & 17.1 & 37.6 & 46.0 & 16.3 \\
\hline \multicolumn{6}{|l|}{ Memorandum item: } \\
\hline Nominal GDP in billions of U.S. dollars & 7.6 & 8.2 & 7.6 & 8.3 & 9.1 \\
\hline
\end{tabular}

1/ Staff estimates, projections, or latest available observations as indicated in the last column.

2/ Current account deficit plus amortization of external debt.

3/ Public sector covers central government only.

4/ Based on averages for the last five years for the relevant variables (i.e., growth, interest rates).

$5 /$ Overall balance plus debt amortization.

6/ ST debt and maturing medium- and long-term debt, domestic and external, excluding external debt to official creditors.

7/ Debt in foreign currency or linked to the exchange rate, domestic and external, excluding external debt on concessional terms.

8/ ST debt and maturing medium- and long-term debt at variable interest rates, domestic and external.

9/ Financial sector includes commercial banks only.

10/ Sum of on- and off-balance sheet exposure. 


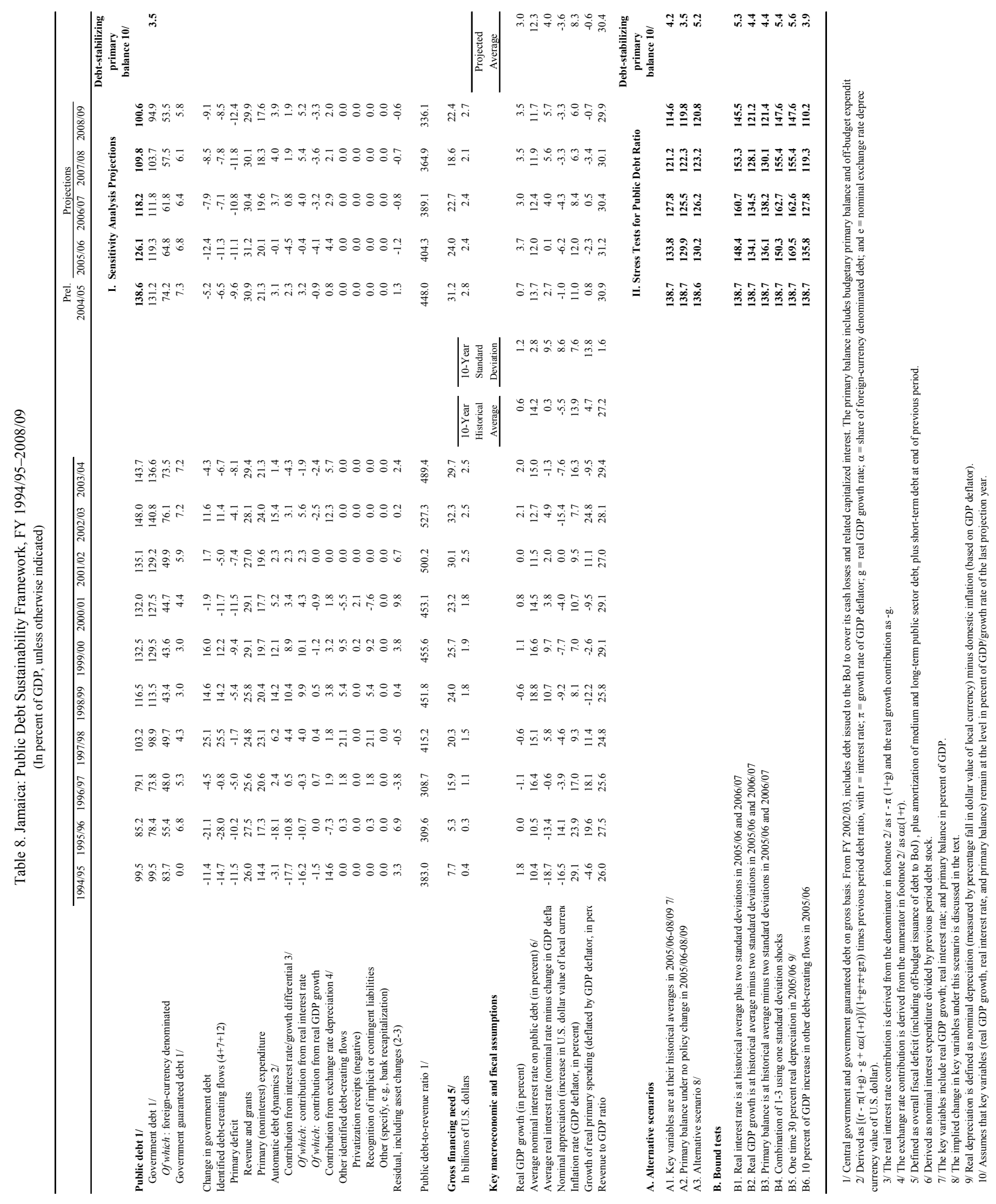




\section{JAMAICA-FUND RELATIONS}

(As of May 31, 2005)

I. Membership Status: Joined February 21, 1963; Article VIII

II. General Resources Account:

Quota

Fund holdings of currency

III. SDR Department:

Net cumulative allocation

Holdings
SDR Million

273.50

273.55

SDR Million

40.61

0.27
Percent of Quota

100.00

100.02

Percent of Allocation

100.00

0.66

IV. Outstanding Purchases and Loans:

None

V. Latest Financial Arrangements:

$\begin{array}{lccrc} & \begin{array}{c}\text { Approval } \\ \text { Date }\end{array} & \begin{array}{c}\text { Expiration } \\ \text { Date }\end{array} & \begin{array}{c}\text { Amount } \\ \text { Approved } \\ \text { (SDR Million) }\end{array} & \begin{array}{c}\text { Amount } \\ \text { Drawn } \\ \text { (SDR Million) }\end{array} \\ & & & & \\ \text { EFF } & 12 / 11 / 92 & 03 / 16 / 96 & 109.13 & 77.75 \\ \text { Stand-by arrangement } & 06 / 28 / 91 & 09 / 30 / 92 & 43.65 & 43.65 \\ \text { Stand-by arrangement } & 03 / 23 / 90 & 05 / 31 / 91 & 82.00 & 82.00\end{array}$

VI. Projected Obligations to the Fund (SDR million); based on existing use of resources and present holdings of SDRs:

\begin{tabular}{lllll}
\multicolumn{5}{c}{ Projections } \\
\hline 2005 & 2006 & 2007 & 2008 & 2009 \\
\hline
\end{tabular}

Principal

$\begin{array}{llllll}\text { Charges/interest } & 0.75 & 1.01 & 1.01 & 1.01 & 1.00 \\ \text { Total } & 0.75 & 1.01 & 1.01 & 1.01 & 1.00\end{array}$

\section{Exchange Rate Arrangements:}

The external value of the Jamaican dollar has been determined in an interbank market operated by commercial banks beginning September 17, 1990. The Jamaican dollar has depreciated significantly since then, though not in a uniform trend. As of March 31, 2005, it was trading at around J\$61 to the U.S. dollar. A multiple currency practice (MCP) exists subject to Fund jurisdiction under Article VIII. The MCP arises from the implementation of the surrender requirement where authorized foreign exchange dealers and cambios are required to surrender at least 5 percent—but not more than 10 percent — of their purchases of U.S. dollars, Canadian dollars and pound sterling to the Bank of Jamaica (BOJ). This surrender requirement is effected based on the previous day's average selling rate for the U.S. dollar, the Canadian dollar, and the pound sterling, respectively, against the Jamaican dollar (referred below as "surrender rates"). 
The surrender rates have resulted in cross rates between the U.S. dollar and the Canadian dollar, and between the U.S. dollar and the pound sterling, that diverge periodically (for more than five days) by more than 1 percent from the midpoint spot exchange rates for those two currency pairs in their principal markets.

\section{Last Article IV Consultation and Program Relations:}

Jamaica is on the standard 12-month consultation cycle, and the last Article IV consultation was completed by the Executive Board on August 4, 2004 (IMF Country Report No. 04/263). Intensified surveillance of the authorities' medium-term macroeconomic and structural policies was requested by the authorities and supported by the Executive Board at the time of the conclusion of 2004 Article IV consultation. The underlying economic strategy was formulated by the authorities without reaching prior understandings with Fund staff. Interim staff reports are prepared for information of the Executive Board in between Article IV consultations, the first of which was issued on January 31, 2005 (IMF Country Report No. 05/61). Jamaica is participating in the Financial Sector Assessment Program in 2005. In this connection, the first of two Fund/World Bank missions visited Jamaica in May, 2005.

\section{Technical Assistance:}

Department Dates

MAE May 1995

October-December 1995

February-June 1996

September 1996

October 1996

February 1997

May 1997

August 1997

January 1998

April 1998

May 1998

April 2001

January 2002

STA September 1996

July 2002

\section{Purpose}

Review of deposit insurance scheme

Banking supervision

Banking supervision

Banking crisis and restructuring

Banking supervision

Central bank accounting

Banking supervision

Banking supervision

Banking supervision

Public debt management

Financial sector restructuring

Banking supervision

Banking supervision

Multisector statistics assessment

Organization of Statistics Office

\section{Resident Representative:}

The post of the resident representative was closed in August 1997. 